\title{
editorial
}

\section{La paz en Colombia: más allá de los acuerdos, más cerca de la sociedad}

DOI: $h t t p: / / d x$.doi.org/10.14483/udistrital.jour.cpaz.2016.1.a00

$\mathbf{E}$ 1 año 2016 será recordado por tres hechos inéditos: 1. La firma de un acuerdo de paz entre el Gobierno de Juan Manuel Santos y las Fuerzas armadas revolucionarias de Colombia (Farc), 2. Lo que trajo como consecuencia el cese del fuego bilateral, y 3 . La convocatoria a la ciudadanía para refrendar los acuerdos de La Habana, Cuba. Pero más allá de la discusión de la conveniencia o no de lo pactado, de lo que se trata aquí, es del reconocimiento explícito que se le ha dado a la importancia de reconstruir las estrategias con las que se había pensado solucionar el conflicto, muchas de ellas reducidas a la obsesión por militarizar a la sociedad o al extremo de ser permisivos ante las peticiones de los actores armados ilegales.

El asunto es mucho más serio, negociar con la guerrilla de las Farc no tiene como fin dar o no gusto a un interés político o personalismo carismático, de lo que se trata en últimas, es de avanzar en una sociedad que debe aunar esfuerzos para neutralizar dinámicas ilegales, o tendientes a desplazar los discursos éticos y morales.

En otras palabras, este país ha convivido con la idea de ver la legalidad y el respeto por la diferencia, como un requisito innecesario para la vida cotidiana y la satisfacción de necesidades básicas de la población. Incluso, buena parte de las regiones del país han terminado por asumir que la violencia es una condición dolorosa, pero necesaria para mantener una estructura de privilegios y prebendas.

Por esa razón, el reto no es otro que asumirnos como sociedad y movilizar la voluntad política y movilidad social para llegar a esas regiones que no han vivido o presenciado las bondades del Estado Social de Derecho, consagrado en la Constitución de 1991.
Nada más perjudicial que luego de refrendado los acuerdos, estas regiones sufrieran un proceso de neocolonización de países con poder económico o nuevos actores armados ilegales, que lleguen a extraer recursos, ofrecer empleos con baja remuneración e injustas condiciones laborales y capitales golondrinas. Lo que se necesita, por el contrario, es que la institucionalidad política y el espíritu académico aparezcan para demostrar que las prácticas ilegales no son adecuadas para promover valores democráticos, respeto por el otro y equidad en el acceso de oportunidades.

En este sentido, la revista Ciudad Paz-ando le apuesta la concepción de una paz multidimensional, entendida esta, como la posibilidad de ir más allá de las causas y consecuencias de las dinámicas de la guerra que ha desangrado a este país durante más de cinco décadas, para proponer estrategias metodológicas e investigativas que ahonden en las realidades locales que han quedado silenciadas por el ruido de los fusiles.

Asuntos como el territorio, la participación política, la formación de ciudadanía, la conexión de la región con los retos del mundo globalizado y la formulación de políticas públicas con un enfoque de respeto a los derechos humanos, se presentan como una ambiciosa, pero necesaria tarea, que se ejerce con el equipo de trabajo, no solo desde la revista, sino desde las actividades cotidianas del Instituto para la Pedagogía, la Paz y el Conflicto Urbano de la Universidad Distrital Francisco José de Caldas-IPAZUD.

Analistas y expertos han coincidido en denominar a los estudiantes de educación superior y posgradual, como los "Profesionales del Posacuerdo", categoría en la que se inscribe la revista que hoy se presenta, pues no podemos darle la espalda a un país que necesita hacer de la construcción 
de paz, una tarea estable y duradera, para los años venideros, en los que no faltaran obstáculos, dificultades y sabotajes, pero que podrán sortearse en tanto trabajemos en colectivo por una visión integral de estudiantes, pero ante todo seres humanos con una comprensión de la Política como el arte de negociar el poder sin recurrir a la amenaza de la muerte, la Sociedad como una categoría conceptual compleja, pero apasionante abordaje para aprender a vivir en el reconocimiento de la otredad y la Paz, como una práctica que no depende las voluntades estatales o resistentes al sistema político.

En ese sentido, la revista que presentamos a los lectores, respeta las condiciones y racionales exigencias de los sistemas de indexación, pero también se da la oportunidad de abrirle la oportunidad a las nuevas generaciones, que desde sus tesis de grado o entusiastas investigaciones, quieren empezar a responder la pregunta que posiblemente en unos años nos harán nuestros hijos y nietos:

\section{¿Qué hicimos en el momento que el país se pre- paraba para cerrar el ciclo doloroso de una violencia dominada por la exclusión y la intolerancia?}

El dossier de esta edición está compuesto de un caleidoscopio de temas, dedicados a indagar sobre esas otras aristas no reconocidas de nuestros conflictos sociales, y cómo estas se pueden resolver, en la medida que tengamos una mirada más flexible y abierta a otras problemáticas que el ruido de las balas no han dejado escuchar. Las desigualdades económicas desde una perspectiva Latinoamericana, las falencias de una educación que le apueste a las estéticas, los vacíos jurídicos en las políticas de discapacidad, los imaginarios de la paz en contextos rurales, la violencia en contextos locales y el rol de la filosofía para pensar en alternativas de solucionar nuestros conflictos, se presentan como rutas osadas, pero propositivas, que seguro cualificarán su relevancia, en el momento en que los grupos armados ilegales dejen de ser la excusa para solucionar nuestros problemas estructurales.

En esta edición reaparecen las secciones voces otras, notas al margen y desde las regiones, para no perder el impulso que la revista ha promovido, para la reflexión de escritos con un pie en la investigación y un pie en la reflexión sopesada, pero animada, de aquellos acontecimientos, que insertos en la coyuntura van narrando nuestra historia.

La sección desde la Cátedra, dedica un breve homenaje a la figura de Camilo Torres en los 50 años de su muerte. En la reseña del libro Recordar es Morir del periodista Daniel Coronell, una frase que por supuesto, nos negamos a que se siga reproduciendo, pues necesitamos un país que abra el espectro a un arcoíris de voces que ponga fin a doscientos años de grises discursos polarizantes.

Cerramos este número, con una entrevista realizada a Cristina Gallego, productora de la galardonada película "El abrazo de la Serpiente", largometraje que golpea los discursos centralistas y el monopolio hollywoodense, para evocar una reflexión sobre los retos de pensar este país de norte a sur, de oriente a occidente.

La revista Ciudad Paz-ando continúa su trabajo, con un pie en la academia, pero con otro pie en el apoyo decidido a las nuevas voces y plumas que quieren abrirse espacios en un país, que en discursos proclama el cambio, pero que en la vida cotidiana, se resiste a la diferencia...pero vamos avanzando paso a paso. 